\title{
Effect of maturity stage on the chemical composition of argan fruit pulp
}

\author{
Hicham Harhar ${ }^{1, *}$, Said Gharby ${ }^{2}$, Yousra El Idrissi ${ }^{1}$, Daniel Pioch ${ }^{3}$, Bertrand Matthäus ${ }^{4}$, \\ Zoubida Charrouf ${ }^{5}$ and Mohamed Tabyaoui ${ }^{1}$ \\ ${ }^{1}$ Laboratory of Nanotechnology, Materials and Environment, Department of Chemistry, Faculty of Science, University Mohammed V, \\ Av. IbnBatouta, BP 1014 Rabat, Morocco \\ ${ }^{2}$ Laboratoire de Physicochimie des Milieux Naturels et Matériaux Bioactifs, Faculté Polydisciplinaire de Taroudant, Université Ibn Zohr, \\ Taroudant, Morocco \\ ${ }^{3}$ UR 114 Biowooeb, Cirad, TA B-114/16 34398 Montpellier Cedex, France \\ ${ }^{4}$ Max Rubner-Institut, Federal Research Institute for Nutrition and Food, Working Group for Lipid Research, Schützenberg 12 , \\ D-32756 Detmold, Germany \\ ${ }^{5}$ Laboratoire de Chimie des Plantes et de Synthèse Organique et Bioorganique, Faculté des Sciences, Université Mohammed V, \\ BP 1014 Rabat, Morocco
}

Received 12 November 2018 - Accepted 11 March 2019

\begin{abstract}
Argan tree, a species endemic to Southern Morroco, is well known for its kernel oil used in cosmetics and health-food, but the corresponding pulp attracted less interest from researchers and little is known about its chemical composition and evolution during maturation. The pulp of argan fruits monthly harvested during the ripening period based on fruit color (April to July), was analyzed. With progressing ripeness various changes were observed in the chemical composition, such as (i) a four-fold increase of total soluble sugars content (glucose, fructose and saccharose), and of $\mathrm{Fe}(75-165 \mathrm{ppm})$, but also (ii) a drop of many components, such as proteins (10.1-6.4\%), and cell wall polymers, lignin (14.9-5.9\%) and hemicellulose and cellulose. Hexane-soluble compounds found in substantial amount (10.7\% in April) also decreased with time: the pulp oil peak (8.3\%) was in April and June, and that of polyisoprene in June (3.6\%). Therefore the stage of maturity (harvest date) is to be considered, without affecting the quality of the argan oil.
\end{abstract}

Keywords: argan pulp / chemical composition / maturity / lipid / micronutrient

Résumé - Effet du stade de maturité sur la composition chimique de la pulpe de fruit d'argan. L'arganier, une espèce endémique du sud du Maroc, est bien connu pour son huile utilisée dans les cosmétiques et les produits diététiques, mais la pulpe correspondante a suscité moins d'intérêt des chercheurs et sa composition chimique et son évolution au cours de la maturation sont peu connues. La pulpe de fruits d'argan récoltée mensuellement au cours de la période de maturation en fonction de la couleur des fruits (avril à juillet) a été analysée. À mesure que la maturité progressait, divers changements ont été observés dans la composition chimique, tels que (i) une augmentation de quatre fois la teneur en sucres totaux solubles (glucose, fructose et saccharose) et de fer (75-165 ppm), mais également (ii) une baisse de nombreux composants, tels que les protéines $(10,1-6,4 \%)$, les polymères de paroi cellulaire, la lignine $(14,9-5,9 \%)$ l'hémicellulose et la cellulose. Les composés solubles dans l'hexane trouvés en quantité substantielle (10,7\% en avril) ont également diminué avec le temps : le niveau maximum d'huile de pulpe $(8,3 \%)$ était en avril et en juin et celui du polyisoprène en juin (3,6\%). Par conséquent, le stade de maturité (date de récolte) doit être pris en compte, sans affecter la qualité de l'huile d'argan.

Mots clés : pulpe d'argan / composition chimique / maturité / lipide / micronutriments

\footnotetext{
*Correspondence: hichamoo79@yahoo.fr
} 


\section{Introduction}

The argan forest was declared as a Biosphere Reserve by UNESCO in 1998 (Harhar et al., 2014) due to its peculiar situation, endemic to the barren lands of Southwest Morocco where it covers an area of 800000 ha (Morton and Voss, 1987). The argan tree (Argania spinosa (L.) Skeels; Sapotaceae) is a slow-growing species, as a shrub or up to ten meters high. Its deep root system helps stabilizing the ground against rain- or wind-induced erosion while its shadow maintains soil fertility by preserving moisture and favoring the growth of different kind of domestic cultures (Charrouf et al., 2002). Leaves are also used as hanging forage for cattle that frequently freely grazes in the forest, argan trees bear fruits that are collected by women, once ripe and fallen on the floor between June and September (Guillaume and Charrouf, 2013). Argan fruit has the size of a big olive and can be round, ovoid, conical or spindleshaped depending on genotypic factors (Guillaume and Charrouf, 2013; Gharby et al., 2013). Just like olive, the fruit is mainly made of two parts, the pulp (mesocarp) which is covered by a skin (epicarp), and the kernel (endocarp) (Fig. 1). Argan oil is produced from the kernel under edible and cosmetic grades (Gharby et al., 2014; Zaanoun et al., 2014). Recently, the production process of argan oil has been modified towards a semi-industrialized method (mechanical cold pressing), and applied in newly developed cooperatives to produce and commercialize virgin argan oil of certified quality (Cayuela et al., 2008; Marfil et al., 2008; Matthäus et al., 2010). Since this edible oil is not refined, fruit quality and processing directly impact on its quality (Cayuela et al., 2008; Marfil et al., 2008; Matthäus et al., 2010). Non-roasted kernels result in argan oil for cosmetics, whereas slightly and carefully roasted kernels deliver the highly prized edible argan oil. It is copper-colored, with a slight hazelnut taste, and is the basic ingredient of the Amazigh diet and its potential health benefits are numerous (Gharby et al., 2011). Both oils are marketed after simple decantation and filtration; they are not refined and therefore they are classified as virgin oils, just like virgin olive oil.

Argan oil composition is well documented (Cayuela et al., 2008; Marfil et al., 2008; Matthäus et al., 2010; Gharby et al., 2011, 2014; Zaanoun et al., 2014). It is characterized by high levels of linoleic and oleic acids, and it is rich in polyphenols and tocopherols (Harhar et al., 2011). In addition, the presence of minor compounds such as sterols, carotenoids, xanthophylls, and squalene contributes to its nutritional value and health properties, and to its dietetic and organoleptic characteristics (Cabrera-Vique et al., 2012). Previous results from our team show that the composition of argan (kernel) oil prepared from fruits collected from the same location does not vary significantly over the three-month April to July period. But a detailed investigation clearly showed that oil extracted from fruits collected in July (fully ripe fruits), differs on the level of minor lipid components (Harhar et al., 2014).

As the pulp of the argan fruit is palatable to cattle and provides a cheap feed for goats and other farm animals, its agricultural impact is of importance. Chemical analysis of argan fruit pulp has already shown the presence of lipids (Charrouf et al., 1991; Charrouf and Guillaume, 1999),

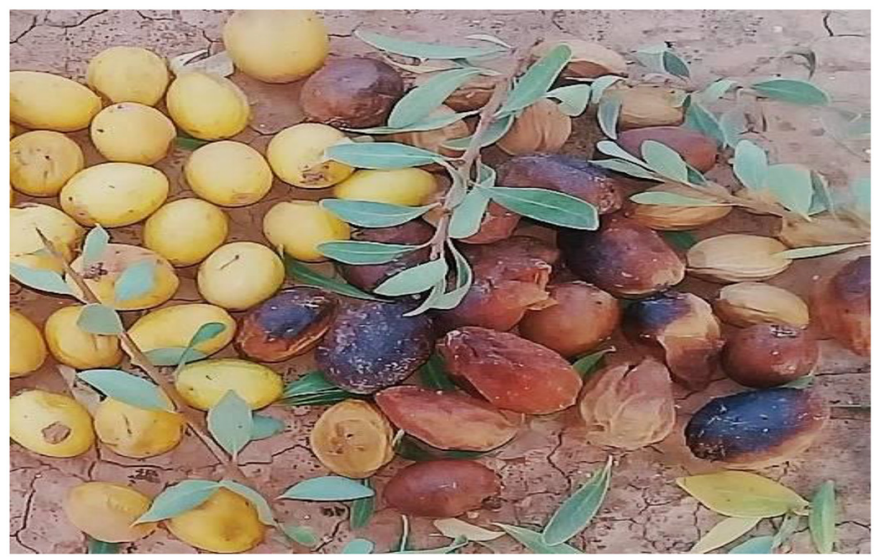

Fig. 1. The main part of argan fruit.

polyisoprene (Pioch et al., 2011), saponins (Charrouf and Guillaume, 1999), and phenolics (Chernane et al., 2000; Charrouf et al., 2007). Pioch et al. (2011) started to set a processing chain aiming at valorizing the pulp, and they pointed the influence of water content on mechanical depulping efficiency of freshly harvested whole fruits.

Whereas these fruits are currently harvested after remaining on the ground for several weeks, it would make sense to pick them at optimum date to ensure proper conservation and processing, optimum organoleptic and commercial quality (Sowmya et al., 2012). This might not be relevant in case of fruits used for kernel oil extraction, but this looks wise when aiming at valorizing the pulp out of its current use as cattle feed. Indeed, overexploitation for pasture and domestic cooking, land clearance for agriculture, climate change, resulted in a decrease in tree density and whole forest area (Alifriqui, 2004; Zugmeyer, 2006), but recent plans to plant again this endangered species, ask for an improved use and valorization of all derived products.

Therefore the aim of the present work was to look for encouraging results to value the pulp without affecting the quality of the argan oil, knowing that the pulp already use is dried for at least 3 weeks which will lose its quality and deteriorated its chemical composition, and to investigate chemical changes occurring in argan pulp as a function of ripening stages during the last months of the one year long maturation. Fruits were collected at different stages of maturity and the pulp was analyzed.

\section{Material and methods}

\subsection{Fruit collection}

Round argan fruits $(20 \mathrm{~kg})$ were collected from four selected trees in Ait Melloul area $(12 \mathrm{~km}$ south of Agadir, Souss-Massa region (Morocco). Harvest dates were April, May, June, and July 2007. Care was taken to collect a representative sample, taking into account the variability of maturity within each tree (based on fruit color). After $3 \mathrm{~h}$ of collection, fruits were peeled manually (we face some problems in peeling even if the fruit was dried), weighed, and processed for in view of analysis. 


\subsection{Moisture content in pulp}

Pulp moisture content was determined by adapting the Association of Official and Analytical Chemists (AOAC) method 934.06 to $5 \mathrm{~g}$ of argan pulp and using a Jouan Quality Systems oven (EU 115 Classe O, France) (Boland, 1998).

\subsection{Lipid and polyisoprene content in pulp}

Determination of oil content in argan pulp was performed following the DIN EN ISO 659:2009 method (ISO 659, 2009). Twenty grams of pulp were placed in a Soxhlet apparatus and extracted with hexane for $8 \mathrm{~h}$. The organic phase was then concentrated under vacuum and dried for $5 \mathrm{~min}$ in an oven at $105^{\circ} \mathrm{C}$. The hexane extract was dissolved in $50 \mathrm{~mL}$ of hexane and then $20 \mathrm{~mL}$ of absolute alcohol was added to coagulate the polyisoprene, the latter is washed with hexane and alcohol 3 times, then polyisoprene was isolated and dried at $50{ }^{\circ} \mathrm{C}$ for $4 \mathrm{~h}$ and weighed; the content of polyisoprene was computed as the percent ratio of polyisprene weight against the dry weight of starting pulp sample. Samples were stored at $4{ }^{\circ} \mathrm{C}$ under nitrogen until analysis.

\subsection{Acidity of lipid fraction}

Oil acidity was determined by titration of a solution of oil in ethanol with ethanolic $\mathrm{KOH}$ and is expressed as percent of oleic acid (ISO 660, 2009).

\subsection{Fatty acid composition of lipids}

Fatty acids composition was determined using method ISO 5508 (1990). In brief, fatty acids (FAs) in above lipid extract were converted to fatty acid methyl esters (FAMEs) before analysis by shaking a solution of $60 \mathrm{mg}$ of oil in $3 \mathrm{~mL}$ of hexane with $0.3 \mathrm{~mL}$ of $2 \mathrm{~N}$ methanolic potassium hydroxide. FMAEs were analyzed by gas chromatography (Varian CP-3800, Varian Inc. Middelburg, The Netherlands) equipped with a flame ionization detector (FID). The column used was a CP-Wax 52CB $(30 \times 0.25 \mathrm{~mm}$ i.d.; Varian Inc.). The carrier gas was helium, and the total gas flow rate was $1 \mathrm{~mL} / \mathrm{min}$. The initial column temperature was $170^{\circ} \mathrm{C}$, the final temperature $230^{\circ} \mathrm{C}$, and the gradient was $4{ }^{\circ} \mathrm{C} / \mathrm{min}$. Injector and detector temperature were $230^{\circ} \mathrm{C}$. Data were processed using Varian Star Workstation v 6.30 (Varian Inc, Walnut Creek, CA, USA). The results were expressed as relative percentage of area of each individual FA pick.

\subsection{Lignocellulosic components in pulp}

Pulp samples were analyzed for content of NDF (Neutral detergent fiber), acid detergent fiber (ADF) and acid detergent lignin (ADL). These parameters were determined according to the methods of Van Soest et al. (1991) using an ANKOM 220 Fiber Analyzer (ANKOM Technology Corporation, NY, USA). Hemicellulose was calculated as NDF - ADF and cellulose as ADF - ADL (Rinne et al., 1997).

\subsection{Sugars in pulp}

A weighed amount ( $1 \mathrm{~g}$ ) of argan fruit pulp (not dried), was suspended in water $(100 \mathrm{~mL})$, sonicated for $10 \mathrm{~min}$, and the mixture was centrifuged; the aqueous extract was then filtered, diluted 1:100 with water prior to injection.

Sugars concentrations were determined using highperformance anion exchange chromatography (HPAEC), on a Carbopac PA-1 analytical column $(4 \times 250 \mathrm{~mm})$. Detection was performed with a pulsed amperometric ED50 detector (Dionex Corp, Sunnyvale, CA, USA). A volume of $25 \mu \mathrm{L}$ was injected. Concentration of each carbohydrate was based on pick area (Chromeleon management system; Dionex) and using calibration curves obtained with corresponding sugar standards (Sigma) (Saint Louis, USA). The elution was achieved isocratically with a $18 \mathrm{mMNaOH}$ solution at a flow rate of $1 \mathrm{~mL} / \mathrm{min}$ (Raessler et al., 2010).

\subsection{Other components}

Crude protein $(\mathrm{CP})$ content was determined by the Kjeldahl method (calculated as $\mathrm{N} \times 6.25$ ), ash content after combustion at $550{ }^{\circ} \mathrm{C}$ using the AOAC 1990 protocol. Sodium, calcium, copper, iron, phosphorus, magnesium, manganese, potassium and zinc, were analyzed by atomic absorption spectrophotometry. One gram of pulp was weighed and dried at $105^{\circ} \mathrm{C}$ for $24 \mathrm{~h}$ in porcelain cup, before charring it in a muffle oven at $550{ }^{\circ} \mathrm{C}$ for $4 \mathrm{~h}$. After cooling, $5 \mathrm{~mL}$ of an hydrochloric acid solution at $20 \%(\mathrm{v} / \mathrm{v})$ were added. Then the mixture was boiled and the content was filtered into a $100 \mathrm{~mL}$ flask competed with deionized water. Mineral elements were determined by atomic absorption spectrometry using a 5000 Perkin Elmer (Überlingen, Germany) with graphite furnace system HGA600 using palladium nitrate as matrix modifier.

\section{Results and discussion}

To our knowledge, argan trees were not really selected for fruit production, although some remarkable trees are known (Harhar et al., 2014). Therefore trees were selected according to fruit shape, as previously described by Gharby et al. (2013). Despite the complexity of argan fruit flowering and maturation cycles, as a broad line, fruit harvested in April, May, June, and July are generally considered by people native of the argan forest as unripe, intermediate, nearly ripe, and fully ripe, respectively. The fruits were collected in a plateau region, near Ait Melloul city, in Morocco, at beginning of every month during the ripening season as described in the previous section and according to Gharby et al. (2013). Fruits were peeled three hours after collection for separating pulp and kernel manually, and the pulp was stored at $4{ }^{\circ} \mathrm{C}$ until analysis for avoiding degradation (fruits infested by Ceratitis capitata worm were discarded).

A portion of each collected sample was analyzed for moisture content. Chemical analysis of the pulp was performed with native or dried pulp upon the case as detailed in the preceding section, to determine the main components. Results are expressed in \% of pulp dry weight unless otherwise specified. Water-insoluble components were extracted with 
Table 1. Evolution of moisture, oil and polyisoprene content in pulp during fruit ripening.

\begin{tabular}{|c|c|c|c|c|}
\hline & April & May & June & July \\
\hline Total hexane extract ( $\%$ dry weight) & $10.7 \pm 0.5$ & $8.7 \pm 0.3$ & $11.9 \pm 0.6$ & $8.4 \pm 0.3$ \\
\hline Polyisoprene (\% dry weight) & $2.6 \pm 0.2$ & $2.0 \pm 0.1$ & $3.6 \pm 0.1$ & $2.7 \pm 0.2$ \\
\hline Oil/polyisoprene ratio & 3.1 & 3.3 & 2.3 & 2.1 \\
\hline
\end{tabular}

hexane, namely neutral lipids (vegetable oil) and polyisoprene, both known as compounds extractable from argan pulp (Pioch et al., 2011); then the polymer was coagulated by adding ethanol to allow separating the lipids, and the corresponding acidity and fatty acid composition were determined. Watersoluble sugars, proteins, cell-wall lignocellulosic components (cellulose, hemicellulose, lignin) and mineral components (ash content and some mineral elements) were also analyzed.

\subsection{Evolution of moisture, lipid and polyisoprene during ripening}

The moisture content did not vary significantly $(p<0.05)$ as visible in Table 1, except between June and July, from an average $81 \%$ down to $77 \%$ at end of survey period. This is the mark of ripening, a reduction in moisture content being generally observed for example for olives (Gracia and León, 2011), almonds (Hawker and Buttrose, 1980) or avocados (Kruger et al., 2000). Accordingly, in the mean-time harvested argan fruits showed a significant change of external color from green to yellow.

Considering the hexane-soluble fraction, the content of oil and polyisoprene in pulp of unripe fruits (green colored peel) was respectively 8.0 and $2.6 \%$ (Tab. 1, April; \% of pulp dry weight). Then it decreased to 6.7 and $2.0 \%$ during the next month (May), but reached its highest value in June ( 8.3 and $3.6 \%$ ) when fruit are considered almost ripe, before falling to the lowest level at end of survey (July; oil 5.7\%; polyisoprene $2.7 \%$ ). The difference between these monthly values being statistically significant, one can conclude that the stage of maturity does influence the lipid content. This is not surprising, to some extent, because in the case of olives for example - another oleaginous pulp - the lipid content increases continuously during ripening (Gracia and León, 2011). However, here the oil content does not follow a simple pattern. This cannot be the result of water uptake, owing to the steady water content already commented; even, the noted small loss of water in July should play against any decrease of oil content. Therefore this variation of oil content can reasonably result from biosynthetic features.

Now regarding polyisoprene, the other pulp component soluble in hexane, we also note in Table 1 that the percentage follows the same pattern as for the oil. But the computed oil to polyisoprene ratio does not stay constant: the highest value (average 3.2) is found in samples harvested in April and May while it drops to 2.2 in June and July samples. Once more this looks to be linked to an evolution of biosynthetic pathways, possibly due to the stress imposed by the very dry season in the area, although the reason and governing parameters remain unknown.

It has also to be taken into account that the content of oil and polyisoprene in pulp reached the maximum value in June (total $11.9 \pm 0.6 \%$ dry weight). Therefore it might be that the supposed end of ripening stage (July regarding collected samples) would be actually an over-ripe stage, if considering the hexane-extractible fraction.

The acidity of extracted pulp oil goes up and down between 8.0 and $16.4 \%$ over the whole period (Tab. 1). It is somewhat surprising to note a quite high value in June (14.8\%) while it was "only" $8.0 \%$ in May. However this pattern follows the one noted for oil content, therefore this might be due to the evolution of biosynthesis of acylglycerols over the harvest period. Although not having the explanation about the variation of these parameters $v s$. harvest date, these results - very high acidity and fluctuations - ask for carefully investigating the influence of harvest procedure, date and conditions on lipid biosynthesis over a longer period of time. Need to recall that in a previous investigation we noted no evolution of the acidity of the corresponding argan kernel oil during the same period, and it was less than $0.2 \%$, indicating that the biosynthesis of triacylglycerols in kernel was almost complete at this stage.

Considering pulp oil composition, the major fatty acids are linoleic and palmitic (close to 29 and 25\% respectively), oleic acid comes third (13-15\%), with a slightly lower percent of linolenic $(\sim 12 \%)$. In spite of the relatively high percentage of saturated acids, the presence of both $\mathrm{C} 18: 2$ and $\mathrm{C} 13: 3$ series makes this oil quite interesting as an edible oil. This composition is different from the one found in the corresponding kernel oil in which found major fatty acids were oleic and linoleic, 51.3 and $30.4 \%$ respectively (Harhar et al., 2014). The fatty acid composition of the pulp oil did not change over the surveyed period, as also previously noted for the kernel oil. Therefore, if considered as a double source of edible oils, argan fruits could be harvested before being considered fully ripe and fallen on the ground in case of targeting the production of edible oils. Available literature data about argan pulp oil shows a quite large variation although all samples containing mainly C18 fatty acids (Tab. 2). FellatZarrouck et al. (1987) found a quite similar composition between pulp and kernel oils, oleic being the major acid (42\%), with equal amounts of linoleic and palmitic acids $(\sim 18.8 \%)$, contrary to the present case showing linoleic as major acid. There are also some differences among the minor fatty acids; for example myristic C14:0 found by Fellat-Zarrouck et al. (1987) (4.3\%), not seen in present case, whereas we detected lauric C12:0 (1.5\%) and erucic acid C22:1 (0.9\%). Variations 
Table 2. Evolution of fatty acid composition of pulp oil during ripening.

\begin{tabular}{|c|c|c|c|c|c|c|c|c|c|}
\hline Fatty acid & \multicolumn{5}{|c|}{ Pulp oil } & \multicolumn{4}{|c|}{ Kernel oil ${ }^{\mathrm{b}}$} \\
\hline Lauric C12:0 & $1.6 \pm 0.1$ & $1.5 \pm 0.1$ & $1.5 \pm 0.1$ & $1.5 \pm 0.1$ & & & & & - \\
\hline Palmitic C16:0 & $24.5 \pm 0.1$ & $25.1 \pm 0.1$ & $25.1 \pm 0.1$ & $25.3 \pm 0.1$ & $18-31$ & 13.3 & 13.2 & 12.9 & 12.5 \\
\hline Palmitoleic C16:1 & $2.1 \pm 0.1$ & $2.3 \pm 0.1$ & $2.2 \pm 0.1$ & $2.5 \pm 0.1$ & & - & - & - & - \\
\hline Linoleic C18:2 & $29.5 \pm 0.1$ & $28.8 \pm 0.1$ & $28.7 \pm 0.1$ & $28.4 \pm 0.1$ & $3-23$ & 30.7 & 30.4 & 30.4 & 30.4 \\
\hline Linolenic C18:3 & $12.2 \pm 0.1$ & $12.0 \pm 0.1$ & $12.5 \pm 0.1$ & $12.5 \pm 0.1$ & $0.4-5$ & - & - & - & - \\
\hline Arachidic C20:0 & $1.8 \pm 0.1$ & $1.8 \pm 0.1$ & $1.8 \pm 0.1$ & $1.9 \pm 0.1$ & 1 & - & - & - & - \\
\hline Erucic C22:1 & $0.9 \pm 0.1$ & $0.9 \pm 0.1$ & $0.9 \pm 0.1$ & $1.0 \pm 0.1$ & - & - & - & - & - \\
\hline
\end{tabular}

${ }^{\text {a }}$ Fellat-Zarrouck et al. (1987).

b Harhar et al. (2014).

between minor acids are not surprising, whereas the shift of oil type between myristic C14:0, oleic C18:1 or linoleic C18:2, asks for an increased work on larger series in order to confirm such changes of major fatty acid that could mark quite differing populations among argan trees.

\subsection{Evolution of cell wall components and soluble sugars}

As already mentioned, the pulp is currently used as feed for cattle. Thus the chemical composition of hexane-extracted argan fruit pulp over the ripening period is given in Table 3. Regarding fibers analyzed according to Van Soest et al. (1991), one notes in Table 3 that NDF (neutral detergent fibers or whole lignocellulosic fibers) does not exceed $31 \%$, meaning that fibers and already presented hexane-extractible amount about $40 \%$ or less; thus other components make the main contribution, and some of them will be discussed later on. NDF content drops from 30.9 to $19.1 \%$ over the period, with no evolution between May and June samples. Other measured data - ADF (acid detergent fibers) and ADL (acid detergent lignin) - follow the same pattern with time. However, when considering the individual components computed from above raw data, worth noting that whereas lignin is by far the main compound in April sample (14.9\%), the three components - lignin, hemicellulose, cellulose - fall into the same range in July $(5.9 ; 6.3 ; 6.8 \%$ respectively). Thus not only the fibers become minor contributors to the pulp, but also their composition changes; in fact the cellulose percentage does not move over the period, resulting in a more prominent cellulosic character of fibers in ripe fruits. This result about cellulose is close to those of Battino (1929) and Dupin (1949) (5.7 and 5.9\%), while a higher value (12.9\% fresh pulp) was possibly found by Fellat-Zarrouck et al. (1987) because of variable moisture content $(20-50 \%)$. Lignin is an indigestible component but provides a smooth gastrointestinal tract and greatly reduces the risk of diarrhea. To our knowledge, no work has dealt with the determination of lignin from the pulp of argan fruits. The low content of lignin in July justifies the use of the argan fruit pulp as cattle feed, although the total fiber content indicates that other components are expected to increase the fodder value of argan pulp.

NDF and ADF contents of argan fruit pulp are lower than the findings of Alcaide et al. (2003) for olive pulp, who reported that NDF and ADF contents of extracted olive pulp was 64.1 and $51.6 \%$, respectively.

Proteins, which are valuable components in fodder, here computed from the nitrogen analysis, are quite low and their content decreases from 10.1 to $6.4 \%$ over the survey period (Tab. 3). This falls in the range found by Battino (1929) and Dupin (1949): 6.2 and 5.1\% respectively (after correction for moisture content). To our knowledge there is no literature reference about the evolution of proteins with time in argan pulp, but Ajana et al. (1999) reported a drop from 4.6 to $2.3 \%$ for Moroccan Picholine olives, thus a similar evolution.

Given the relatively low content of proteins in July, sugars - another group of nutrients in fodder - were also investigated. The total soluble sugars increased drastically between April and July, from 3.9 up to $15.7 \%$ (Tab. 4), thus becoming the first class of investigated pulp components, before any individual cell wall polymers (cellulose, hemicellulose, lignin), and close to the total fiber content (19.1\%). A closer look shows that this class comprises essentially three components; glucose, the main one in all samples, increases from 2.2 up to $5.6 \%$. Saccharose, the second ranked in April experiences the strongest change from 1.0 to $7.5 \%$, becoming the main sugar in July. Fructose stays third ranked but also increases, from 0.6 to $3.6 \%$. Rhamnose was detected only in April sample.

The fact that xylose or mannose, galactose, arabinose were not detected does not play in favor of these soluble sugars originating from hemicellulose hydrolysis. Indeed Table 3 shows that hemicellulose stayed rather stable, with a drop of only $1.9 \%$ over the period. Same remark applies to cellulose, the drop being even smaller (only 1.0\%). Thus saccharose and its two constituents fructose and glucose are likely to result from de novo synthesis during the very last months of argan fruit ripening, similarly to other fruits, as usual in many fruit pulps. Sandret (1956) pointed soluble sugars as main components of total carbohydrates in pulp. Also, AbougheAngone et al. (2008) investigated extensively the insoluble 
Table 3. Evolution of pulp cake composition during ripening.

\begin{tabular}{|c|c|c|c|c|}
\hline (\% dry weight) & April & May & June & July \\
\hline $\mathrm{ADF}$ & $22.7 \pm 1.4$ & $17.3 \pm 1.3$ & $16.9 \pm 1.2$ & $12.7 \pm 1.3$ \\
\hline NDF-ADL (hemicellulose) & $8.2 \pm 0.3$ & $7.3 \pm 0.5$ & $7.3 \pm 0.4$ & $6.3 \pm 0.1$ \\
\hline ADF-ADL (cellulose) & $7.8 \pm 0.3$ & $7.7 \pm 0.3$ & $7.3 \pm 0.2$ & $6.8 \pm 0.4$ \\
\hline
\end{tabular}

NDF: neutral detergent fiber; ADF: acid detergent fiber; ADL: acid detergent lignin.

Table 4. Evolution of soluble sugars in pulp during ripening.

\begin{tabular}{|c|c|c|c|c|c|}
\hline (\% dry weight) & Rhamnose & Glucose & Fructose & Saccharose & Total \\
\hline May & 0.00 & 6.2 & 3.0 & 2.7 & 11.9 \\
\hline July & - & 5.6 & 3.6 & 7.5 & 15.7 \\
\hline
\end{tabular}

Standard deviation: $0.01 \%$ or less $(0.01 \%$ in case of rhamnose).

Table 5. Effect of harvest date on $\mathrm{P}$ and mineral cations in fruit pulp.

\begin{tabular}{lllllllrrr}
\hline & $\mathrm{P}(\mathrm{ppm})$ & $\mathrm{K}(\%)$ & $\mathrm{Ca}(\%)$ & $\mathrm{Mg}(\%)$ & $\mathrm{Na}(\%)$ & $\mathrm{Cu}(\mathrm{ppm})$ & $\mathrm{Fe}(\mathrm{ppm})$ & $\mathrm{Mn}(\mathrm{ppm})$ & $\mathrm{Zn}(\mathrm{ppm})$ \\
\hline April & 850 & 2.8 & 0.28 & 0.10 & 0.20 & 1.5 & 75.6 & 11.2 \\
May & 770 & 2.6 & 0.25 & 0.09 & 0.19 & 1.7 & 57.7 & 9.7 & 5.9 \\
June & 820 & 2.5 & 0.24 & 0.09 & 0.18 & 1.6 & 100 & 9.1 & 4.7 \\
July & 650 & 2.1 & 0.19 & 0.07 & 0.14 & 1.5 & 165 & 8.5 \\
\hline
\end{tabular}

sugars fraction, and concluded that the major constituents in pulp cell walls are a galacto-xyloglucan among the polysaccharides, together with arabinogalactan-proteins, galactose and arabinose making $70 \%$ of total oligosaccharides in pulp. As a matter of fact Heuzé et al. (2015a) reported average total sugars and gross energy content in pulp close to those of destoned olive cake $(15.3 \%$ and $18.2 \mathrm{~kJ} / \mathrm{kg} ; 14.5 \%$ and $20.6 \mathrm{~kJ} /$ $\mathrm{kg}$ ) and to oil palm press fibers $(18.3 \mathrm{~kJ} / \mathrm{kg})$, both derived from the pulp of an oleaginous fruit similar to argan fruit. Our results complement scarce information available from literature about pulp composition, and confirm the reported high nutritional value of argan fruit pulp (estimated to be $70-100 \%$ of that of barley by Sandret (1956)), among other co-products of argan tree cultivation and processing chain (Heuzé and Tran, 2015b). Also we noted that late harvest maximizes the soluble sugars content but minimizes the content of sugars-containing cell wall polymers.

\subsection{Ash and micronutrients}

Last investigated pulp fraction deals with phosphorus and metals in the mineral residue or ash which can bring useful nutriments in feeding livestock or as fertilizer. There is a slight decrease between April and July (7.6 to 5.5\%; Tab. 3). The same values were also found by Fellat-Zarrouck et al. (1987) and Dupin (1949), (respectively 4.1 and 4.6\%), however Battino (1929) showed a remarkable lower content compared to our results $(0.2 \%)$. These values are higher than those in cakes of peanut, cottonseeds and soybeans (3.7\%), and olive fruits (2.7-5.5\%) (Ajana et al., 1999).

Concentrations of selected macro- and micronutrients during the ripening of argan fruit pulp are given in Table 5. Potassium was the major macronutrient, as in other pulps like apple, quince, loquat, apricot (Lo-Voi et al., 1995) and kiwi (Castaldo et al., 1992), but also in destoned olive cake (Heuzé et al., 2015a). Then come, ranked by decreasing content, calcium, phosphorus, magnesium. Among the analyzed micronutrients the level of iron was by far higher than that of manganese, zinc and copper. Iron is also a major micronutrient in many fruits (Glew et al., 2003), such as lemon, orange and grapefruit (Gorinstein et al., 2001), although there is a wide variability even within a given species depending on climate, soil and cultivation techniques (Greenfield and Southgate, 1992). Among all analyzed 
nutriments, iron experienced the largest variation, the lowest and highest values corresponding respectively to unripe and to ripe pulps, from 58 to $165 \mathrm{ppm}$.

\section{Conclusion}

While most research efforts concerning the argan fruit for decades were focused on the kernel and its derived high value oil ("argan oil") owing to the increasing uses in food and cosmetics, there was a lack of information about the pulp. This preliminary research work starts to fill the gap: main constituents were monitored during fruits ripening, when color turns from green to yellow, just before falling on the ground. Significant variations were found for oil and polyisoprene, the last one being at maximum in June, whereas the former was as high in April as it was in June, but here again the July sample was not suitable for maximizing pulp oil yield.

Same remark applies to proteins and to hemicellulose and cellulose - a source of fermentable sugars - highest in April, staying at high level until June, but noticeably lower in July. The sole exception concerns the soluble sugars of which total content showed a four-fold increase during the surveyed period. Therefore the supposed fully mature stage in July, based on color change, does not look to be preferred time for an optimized multiple-products valorization of the pulp (for example pulp oil, latex and fodder for goats), the innovative target that led to this study. An earlier harvest would not impede kernel oil yield as already experienced, and would still provide the extracted pulp cake as fodder for local farmers. These results ask for a detailed investigation (i) of lipid and polyisoprene biosynthesis, in order to optimize harvest date and to maximize extraction yields, but also (ii) of the factors acting on the found variability of monitored pulp components when comparing our results to those in literature.

Acknowledgements. This work was funded by "Projet Arganier" and financially supported by "Agence de Développement Social" and EEC (\#AR05A061P704). We thank Association Ibn Al Baytar and, Argan oil cooperative of Tiout, for their support and assistance in this work.

\section{References}

Aboughe-Angone S, Nguema-Ona E, Ghosh P et al. 2008. Cell wall carbohydrates from fruit pulp of Argania spinosa: Structural analysis of pectin and xyloglucan polysaccharides. Carbohydr Res 343: 67-72.

Ajana H, EL Antari A, Hafidi A. 1999. Evolution of biometric parameters and chemical composition of olives from Moroccan Picholine variety fruit ripeness. Grasas Aceites 50: 1-16.

Alcaide EM, Yanez Ruiz D, Moumen A, Martın Garcıa I. 2003. Chemical composition and nitrogen availability of some olive byproducts. Small Rumin Res 49: 329-336.

Alifriqui M. 2004. L'écosystème de l'arganier. Étude réalisée pour le Programme des Nations unies pour le développement (PnudMaroc). $126 \mathrm{p}$.

AOAC (Association of Official Analytical Chemists). 1990. Official Methods of Analysis (OMA), 15th Ed. Arlington, Virginia, USA: AOAC.

Battino M. 1929. Recherches sur l'huile d'argan et sur quelques autres produits de l'arganier. Paris: Libraire le français, $132 \mathrm{p}$.
Boland FE. 1998. AOAC official method 934.06. Official methods of analysis of AOAC International, 16th Ed., 4th revision, Vol. II. Gaithersburg, MD: AOAC International, $4 \mathrm{p}$.

Cabrera-Vique C, Marfil R, Giménez R, Martínez-Augustin O. 2012. Bioactive compounds and nutritional significance of virgin argan oil - An edible oil with potential as a functional food. Nutri Rev 70: 266-279.

Castaldo D, Lo Voi A, Trififro A, Gherardi S. 1992. Composition of Italian kiwi (Actinidia chinensis) puree. J Agri Food Chem 40: 594-598.

Cayuela JA, Rada M, Pérez-Camino MC, Benaissa M, Abdelaziz E, Guinda A. 2008. Characterization of artisanally and semiautomatically extracted argan oils from Morocco. Eur J Lipid Sci Technol 110: 1159-1166.

Charrouf Z, Fkih-Tétouani S, Charrouf M, Mouchel B. 1991. Triterpènes et stérols extrait de la pulpe d'Argania spinosa (L.) Sapotaceae. Plantes médicinales et phytothérapie XXV(2-3): 112-117.

Charrouf Z, Guillaume D. 1999. Ethnoeconomical, ethnomedical, and phytochemical study of Argania spinosa (L.) Skeels. J Ethnopharmacol 67: 7-14.

Charrouf Z, Guillaume D, Driouich A. 2002. The argan tree: An asset for Morocco (in french). Biofutur 220: 54-57.

Charrouf Z, Hilali M, Jauregui O, Soufiaoui M, Guillaume D. 2007. Separation and characterization of phenolic compounds in argan fruit pulp using liquid chromatography-Negative electrospray ionization tandem mass spectroscopy. Food Chem 100: 1398-1401.

Chernane H, Hafidi A, Ajana H. 2000. Evolution of biometric parameters and fatty acid composition of oil of four argan tree fruit types (Argania spinosa Skeels) during ripening. Agrochimica 44: $180-196$.

Dupin A. 1949. L'arganier survivant de la flore tertiaire providence du sud marocain, élevage et cultures, vol.3, pp.28-34.

Fellat-Zarrouck K, Smoughen S, Maurin R. 1987. Étude de la pulpe $\mathrm{du}$ fruit de l'arganier (argania spinosa) du Maroc. Matière grasse et latex. Actes Inst Agron Vet 7: 17-22.

Gharby S, Harhar H, Guillaume D, Haddad A, Matthäus B, Charrouf Z. 2011. Oxidative stability of edible argan oil: A two year study. LWT- Food Sci Technol 44: 1-8.

Gharby S, Harhar H, Kartah B, Guillaume D, Charrouf Z. 2013. Chemical changes in extra virgin argan oil after thermal treatment. Nat Prod Com 8: 29-31.

Gharby S, Harhar H, Guillaume D et al. 2014. Oxidative stability of cosmetic argan oil: A one-year study. J Cosmet Sci 65(2): 81-87.

Glew RH, Ayaz FA, Vanderjart DJ, Millson M, Dris R, Niskanen R. 2003. Mineral composition of medlar (Mespilus Germanica) fruit at different stages of maturity. J Food Qual 26: 441-447.

Gorinstein S, Martin-Belloso O, Park YS et al. 2001. Comparison of some biochemical characteristics of different citrus fruits. Food Chem 74: 309-315.

Gracia A, León L. 2011. Non-destructive assessment of olive fruit ripening by portable near infrared spectroscopy. Grasas Aceites 62: 263-268.

Greenfield H, Southgate DAT. 1992. Food composition data: Production, management and use (1st Ed.). London and New York: Elsevier.

Guillaume D, Charrouf Z. 2013. Argan oil for nutritional and skin care applications. H\&PC Today 8: 28-30.

Harhar H, Gharby S, Kartah B, Pioch D, Guillaume D, Charrouf Z. 2014. Effect of harvest date of Argania spinosa fruits on argan oil quality. Ind Crop Prod 56: 156-159.

Harhar H, Gharby S, Kartah B, El Monfalouti H, Guillaume D, Charrouf Z. 2011. Influence of argan kernel roasting-time on 
virgin argan oil composition andoxidative stability. Plant Food Hum Nutr 66: 163-168.

Hawker JS, Buttrose MS. 1980. Development of the almond nut (Prunus dulcis (Mill.) D. A Webb): Anatomy and chemical composition of fruit parts from anthesis to maturity. Ann Bot 46: 313-321.

Heuzé V, Tran G, Gomez Cabrera A, Lebas F. 2015a. Olive oil cake and by-products. Feedipedia, a programme by INRA, CIRAD, AFZ and FAO. Available from http://www.feedipedia.org/node/ 32 (last updated: 2015/11/05).

Heuzé V, Tran G. 2015b. Argan (Argania spinosa). Feedipedia, a programme by INRA, CIRAD, AFZ and FAO. Available from http://www.feedipedia.org/node/54, Nutritional aspects, Ruminants (last updated: 2015/26/10).

ISO 5508. 1990. Animal and vegetable fats and oils - Analysis by gas chromatography of methyl esters of fatty acids.

ISO 659. 2009. Oilseeds-Determination of oil content (Reference method). EN ISO 659.

ISO 660. 2009. Animal and vegetable fats and oils - Determination of acid value and acidity.

Kruger FJ, Kritzinger M. Malumane R. 2000. Recommendations for controlling the post-harvest problems of the Pinkerton cultivar. South Afr Avocado Grow Assoc Yearb 23: 8-14.

Lo-Voi A, Impembo M, Fasanaro G, Castaldo D. 1995. Chemical characterisation of apricot puree. J Food Compos Anal 8: 78-85.

Marfil R, Cabrera-Vique C, Giménez R, Bouzas PR, Martinez O, Sanchez JA. 2008. Metal content and physicochemical parameters used as quality criteria in virgin argan oil: Influence of the extraction method. J Agric Food Chem 56: 7279-7284.

Matthäus B, Guillaume D, Gharby S, Haddad A, Harhar H, Charrouf Z. 2010. Effect of processing on the quality of edible argan oil. Food Chem 120: 426-432.
Morton JF, Voss GL. 1987. The argan tree (Argania sideroxylon, sapotaceae), a desert source of edible oil. Econ Bot 41: 221-233.

Pioch D, Buland F-N, Pingret D et al. 2011. Valorization of the pulp of Argania spinosa L. Processing and products-Towards an optimized valorization of the argan fruit. In: Proceedings of the First International Congress of Argan Tree, Agadir, 15-17 December 2011, pp.215-222, Available from http://www.inra. org.ma/Docs/actesarganier/arganier215222.pdf.

Raessler M, Wissuwa B, Breul A, Unger W, Grimm T. 2010. Chromatographic analysis of major non-structural carbohydrates in several wood species-An analytical approach for higher accuracy of data. $R$ Soc Chem Anal Method 2: 532-538.

Rinne M, Jaakkola S, Huhtanen P. 1997. Grass maturity effects on cattle fed silage-based diets. 1. Organic matter digestion, rumen fermentation and nitrogen utilization. Anim Feed Sci Tech 67: 1-17.

Sandret FG. 1956. Étude préliminaire de la composition chimique de la pulpe d'argan et de ses variations au cours de la maturation. Ph.D. Thesis, École marocaine d'agriculture, Meknès, Morocco, $55 \mathrm{p}$.

Sowmya KJ, Gowda R, Balakrishna P, Gururaja Rao MR. 2012. Effect of fruit maturity stages on seed quality parameters in jatropha (jatropha curcas L). Indian J Plant Sci 1: 85-90.

Van Soest PJ, Robertson JB, Lewis BA. 1991. Methods for dietary fiber, neutral detergent fiber, and nonstarch polysaccharides in relation to animal nutrition. J Dairy Sci 74: 3583-3597.

Zaanoun I, Gharby S, Bakass I, Ait addi E, Ait ichou I. 2014. Kinetic parameter determination of roasted and unroasted argan oil oxidation under Rancimat test conditions. Grasas Aceites 65(3): e033.

Zugmeyer L. 2006. Projet de développement sylvo-pastoral de l'arganeraie marocaine (Commune Rurale de Tiout, Taroudant, Maroc). Mémoire de fin d'études, École Nationale du Génie Rural, des Eaux et des Forêts, Nancy, France.

Cite this article as: Harhar H, Gharby S, El Idrissi Y, Pioch D, Matthäus B, Charrouf Z, Tabyaoui M. 2019. Effect of maturity stage on the chemical composition of argan fruit pulp. OCL 26: 15. 